\title{
Effects of Climate Change on Tropical Forest Ecosystem of Three Selected Local Government in Rivers State, Nigeria
}

\author{
*NNADI, P.C; AMADI, G.O \\ Department of Forestry and Environment, Rivers State University, Nkpolu Oroworukwo, Port Harcourt, Rivers State, Nigeria \\ *Corresponding Author Email: picasolng@yahoo.com
}

\begin{abstract}
This study evaluated changes in climate on tropical rainforest ecosystem in three Local Government Area of Rivers state, Nigeria. Structured questionnaires were administered randomly to 300 respondents. $89.7 \%$ affirms that they are aware of the change in climate, $10.3 \%$ were not aware. $33.6 \%$ attribute the source of their awareness to village leaders/neighbours and relations, $28.3 \%$ Radio, $17.7 \%$ television, $13.7 \%$ internet and $6.7 \%$ newspaper. On the causes of climate change, 32.7 attributes the cause to deforestation, $21.7 \%$ Urbanization and $20.7 \%$ Logging. 89.3\% affirmed to being aware of the health implication of climate change, $10 \%$ were not aware while $0.7 \%$ were undecided. On the current state of the Tropical forest $82.7 \%$ expressed regret, $10 \%$ had no regret while $7.3 \%$ were undecided. $56 \%$ attest to loss in some indigenous specie while $44 \%$ were not aware. This research reveals that tropical forest ecosystems have been depleted and this has been attributed to human activities which include deforestation, urbanization, etc. leading to loss of forest. Enlightenment/awareness campaigns will help curtail further depletion of the forest.
\end{abstract}

\section{DOI:https://dx.doi.org/10.4314/jasem.v23i1.13}

Copyright: Copyright $(0) 2019$ Nnadi and Amadi. This is an open access article distributed under the Creative Commons Attribution License (CCL), which permits unrestricted use, distribution, and reproduction in any medium, provided the original work is properly cited.

Dates: Received: 02 November 2018; Revised: 09 January 2018; Accepted 19 January 2018

Keywords: Climate Change, Species loss, Health perception, Ecosystem

Forests cover large area of the earth than other types of vegetation, they have been and continues to be beneficial in man's everyday life; its importance cannot be over emphasized (Ukoima et al, 2014) as they play critical role to man's existence due to the products gotten from it (Timber and Non timber forest products). The tropical forest is a source of livelihood to dwellers living around as it's products or produce are essential to man's everyday living. Humans depend on lots of products from the forest which they exploit to satisfy their needs. The benefits that are derived from it are immeasurable / unquantifiable, some of which are: the release of oxygen to the atmosphere during photosynthesis, the extraction of carbon from the atmosphere, keeping temperature within a range necessary for species survival, provides shelter for wildlife, recreation activities, medicinal plants, etc. All these help to maintain better living conditions. The forest is often believe to be unchanging due to tree life span but Undeniably in recent time the forest ecosystem is fast depleting, this is a cause for serious concern environmentally and economically since it is without monitoring (Abere et al., 2011). This reduction has been attributed majorly to man's incessant activities ranging from urbanization, industrialization, deforestation, population explosion, etc. and this has led to climate change which has an adverse effect on the social, economic and health of humans and society at large. The United Nations Framework Convention on Climate Change (UNFCC 1992) defines "climate change as a change which is attributed directly or indirectly to human activity that alters the composition of the atmosphere globally over a comparable period of time leading to increase in average temperatures, this is primarily induce by increase in greenhouse gases such as Carbon Dioxide $(\mathrm{CO} 2)$. Several negative experiences affecting livelihood has been attributed to this change and that have made it a major global concern in the world today. Africa is presently experiencing severe impact of climate change Olajide (2016). This change is a phenomenon that has been observed and various studies have been carried out. It is environmental issues that affect tropical regions in diverse ways as it threatens large number of specie. This needs to be dealt with for man continual existence. This change has affected the tropical region in diverse ways, it threatens the existence of large number of species (Winjum and Schneider 1997) as seen when recent data are compared with previous data. A report by the IPCC in 2007 on West Africa projected temperature to increase by 2.0 to $6.0^{\circ} \mathrm{C}$ relatively to the present by the $21^{\text {st }}$ century. This increase leads to loss of biodiversity, shortage in food, environmental degradation, etc. The foregoing implies that 
identifying the effects of climate change is crucial to understanding, formulating and implementing of policies on control and prevention of factors that cause it. This becomes very imperative since it will enhance survival of lives and good living condition. This paper aims to evaluate the effects of climate change in tropical forest ecosystem of three local government areas in Rivers state, Nigeria.

\section{MATERIALS AND METHODS}

Data collection: Data were obtained with the aid of a structured questionnaire that was been administered to over 300 respondents between the ages of 18 to 65 years; questions were focused on assessing the socio - economic status of the respondents as well as to solicit relevant information base on the objectives of this work. Data Analysis: Data derived from the study were analysed using Descriptive statistics such as tables, frequency and percentage. For each Local Government Area, Communities/clans were chosen due to their closeness to forest areas; One hundred (100) questionnaires were earmarked for each of the selected areas and administered to respondents. Some of the questions are presented in Table 1:

\section{Table 1: Questionnaire}

\begin{tabular}{|c|c|c|c|}
\hline 1 & Are you aware of climate change and its causes? & Yes & No \\
\hline 2 & If yes, what is/are the causes & & \\
\hline 3 & Has there been any health implication as a result of this changes & Yes & No \\
\hline 4 & What are your feelings/perception about the tropical forest & Regrettable & Non-Regrettable \\
\hline 5 & If regrettable, state reasons & & \\
\hline 6 & Has the forest in your locality remain intact & Yes & No \\
\hline 7 & What informs you about the changes in the ecosystem & Yes & No \\
\hline 8 & Has there been a loss in species & Yes & No \\
\hline 9 & Has the temperature in your environment change when compared to 15 years and above & & \\
\hline
\end{tabular}

\section{RESULTS AND DISCUSSION}

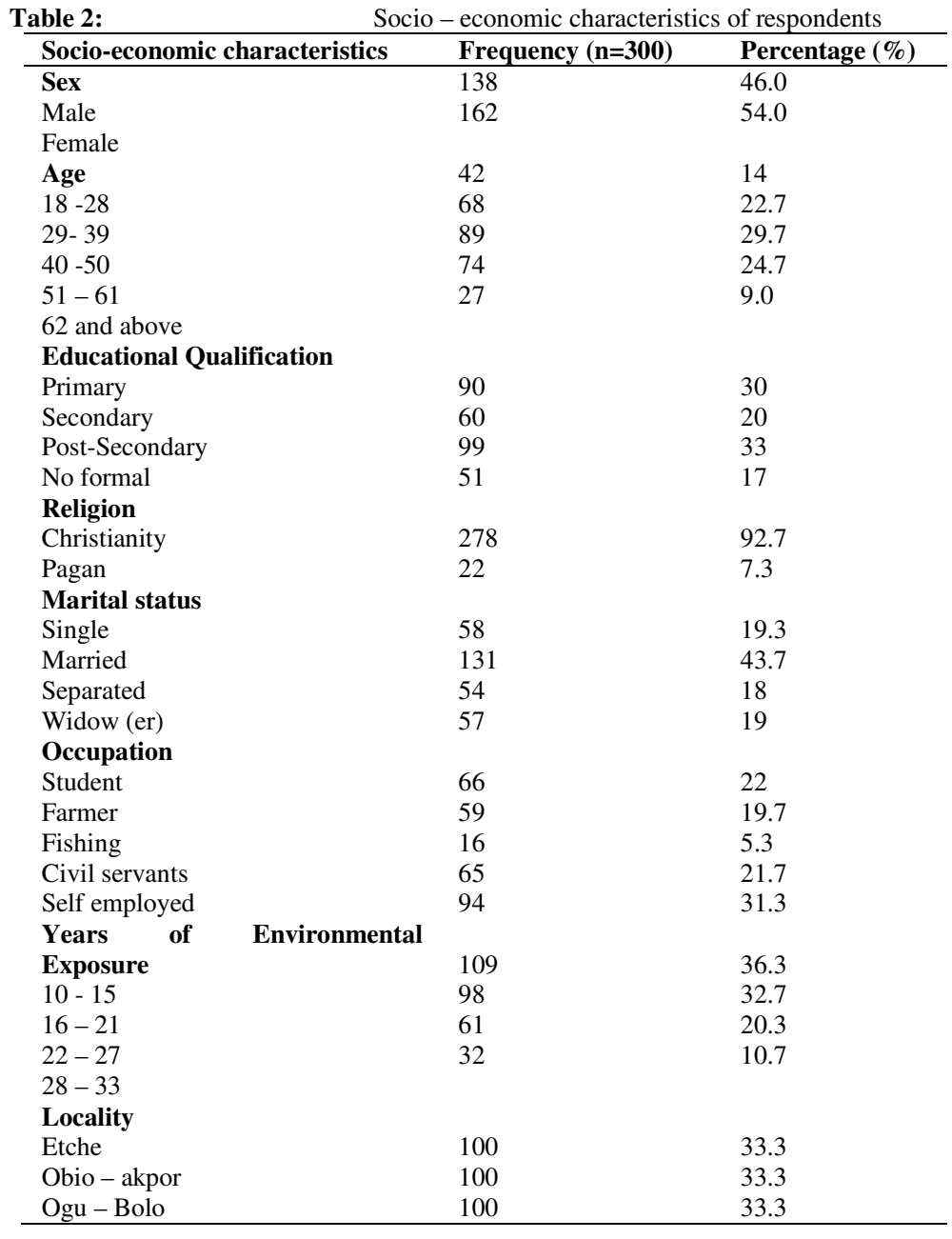

The selected socio-economic characteristics of the respondents in this study were sex, age, highest educational qualification, religion, marital status, occupation, locality and years of environmental awareness. From the analysis shown in table 2, the respondents attended to is $54.0 \%$ Female and $46.0 \%$ male.

The female were more, this is attributed to their less busy schedule making them to be much around. Majority of the respondent falls within the age brackets of 40 $50(29.7 \%)$, which are mainly the age bracket open to new idea and innovation or said to be the productive age. Of the total number of respondents, $92.7 \%$ practiced Christianity as their religion while $7.3 \%$ of the respondents are pagans. This proved that the knowledge about environment is known by all religion and also implies that there is no religious taboo. In the study area, $43.7 \%$ of the respondent were married, $18.0 \%$ separated, $19.3 \%$ single and $19.0 \%$ were widow (er). As shown in the analysis, the category of 
respondent within $10-15$ years range of experience is $36.3 \%, 16-$ 21 years are $32.7 \%$, and $22-27$ years are $20.3 \%$ while $28-33$ years are $10.7 \%$. This is in contrast to the statement of Akinbile (2004), which states that "most of those with the environment, forest and farming in Nigeria are old with young people preferring white collar jobs". Occupation of the respondents as stated in the table shows that majority $(31.3 \%)$ are self-employed, $21.7 \%$ are civil servant/employed while students, farmers and fishers percentage are $22.0 \%, 19.2 \%$ and $5.3 \%$ respectively. The three (3) selected Local Government as stated in the table shows Obio-Akpor, Etche and Ogu-Bolo having 33.3\% each. This proves that equal attention was given. The educational qualification of the respondents shows that majority (30\%) of the respondent completed primary education, 20\% Secondary, 33\% postsecondary while no formal education has $17 \%$. The majority shows the enlightened nature of the society.

Climate Change Awareness in study area: On climate change awareness, from the analysis of the response $89.7 \%$ affirmed to be aware while $10.3 \%$ responded in the opposite. This support the report of Stern (2007) that climate change agenda is now at the centre of public consciousness, this implies that there has been an increase in the level of awareness. From the analysis in table 3, majority (33.6\%) of the respondents attributed their information source to village leaders/neighbours/relatives, $28.3 \%$ identified radio, $17.7 \%$ identified television while internet and newspaper were $13.7 \%$ and $6.7 \%$ respectively. The finding shows that $89.7 \%$ of the respondents are aware of a cause of climate change while $10.3 \%$ are not aware.

Table 3 Distribution of Respondents on climate change/source of awareness in the study

\begin{tabular}{|c|c|c|}
\hline Awareness/ & Frequency $(n=300)$ & Percent (\%) \\
\hline Yes & 269 & 89.7 \\
\hline No & 31 & 10.3 \\
\hline \multicolumn{3}{|l|}{ Source } \\
\hline Internet & 41 & 13.7 \\
\hline Radio & 85 & 28.3 \\
\hline Television & 53 & 17.7 \\
\hline Village leaders/Neighbours/Relations & 101 & 33.6 \\
\hline Newspaper & 20 & 6.7 \\
\hline
\end{tabular}

Table 4 Distribution of respondents on causes of climate change effect

\begin{tabular}{lll}
\hline Causes & Frequency $(\mathbf{n = 1 2 0})$ & Percent $(\boldsymbol{\%})$ \\
\hline Deforestation & 98 & 32.7 \\
Industrialization & 65 & 21.7 \\
Logging & 62 & 20.7 \\
Urbanization & 71 & 23.7 \\
\hline \multicolumn{3}{c}{ Source: Field survey, 2017 }
\end{tabular}

Most (32.7\%) attributed the cause of climate change effect to deforestation, followed by urbanization with $21.7 \%$ while industrialization and logging has $20.7 \%$ and $23.7 \%$ respectively. This to an extent support FAO (2007) report that over $90 \%$ of trees were cut in Africa and use as fuelwood.

Effect of Climate on Health: Table 5 shows that $89.3 \%$ of the respondents were of the opinion that the changing climatic condition has impact on the well-being of humans, $10 \%$ where not of the opinion while $0.7 \%$ was undecided. This finding support Elsio et al., (2014) who reported that the ecosystem in which plants and animals lives depends on undergoes changes whenever the vegetation does, these on the long run have impacts on humans and that of Winjum et al., (1997) that the change threatens the existence of large number of species. This implies that sensitization needs to be carried out to showcase how changing climate affects health.

Table 5. Climate change and health awareness

\begin{tabular}{lll}
\hline $\begin{array}{l}\text { Health } \\
\text { Implication } \\
\text { awareness }\end{array}$ & $\begin{array}{l}\text { Frequency } \\
(\mathbf{n = 3 0 0 )})\end{array}$ & $\begin{array}{l}\text { Percent } \\
(\boldsymbol{\%})\end{array}$ \\
\hline Yes & 268 & 89.3 \\
No & 30 & 10 \\
Undecided & 2 & 0.7 \\
\hline Source: Field survey, 2017
\end{tabular}

Tropics Perception: As shown in table $6,82.7 \%$ of respondents express regret on loss of species and other effects, $10 \%$ non - regret while $7.3 \%$ were undecided.

Table 6: Perception of Localities and their response on species on species loss

\begin{tabular}{lll}
\hline $\begin{array}{l}\text { Tropics } \\
\text { ecosystem }\end{array}$ & $\begin{array}{l}\text { Frequency } \\
(\mathbf{n = 3 0 0 )}\end{array}$ & $\begin{array}{l}\text { Percent } \\
(\%)\end{array}$ \\
\hline $\begin{array}{l}\text { Perception of } \\
\text { tropics }\end{array}$ & & \\
$\begin{array}{l}\text { Regrettable } \\
\text { Non }\end{array}$ & 248 & 82.7 \\
regrettable & 30 & 10 \\
$\begin{array}{l}\text { Undecided } \\
\text { Loss } \\
\text { species }\end{array}$ & 22 & 7.3 \\
Yes & & \\
No & 168 & 56 \\
\hline \multicolumn{2}{l}{$\begin{array}{l}\text { Source: Field survey, 2017 } \\
\text { 132 }\end{array}$} \\
\hline
\end{tabular}

On the loss of species, majority affirms to specie loss, this supports the work of Gonzalez, 2001 that forest is at a high risk due to climate change which in severe situation or case could lead to species loss especially at the margins of the ecosystem and that of Nnadi et al., (2014) on the extinction of some indigenous economic fruit tree $s p p$ as a result of Deforestation. 
Conclusion: The tropical forest ecosystems from findings have been depleted and this has been attributed to human activities which include deforestation, urbanization, etc. leading to loss of forest as attested by majority of respondents in the study area. Climate change, its effect and solution strategies do not generate great publicity effects today. But can, if enlightenment/awareness campaigns are carried out as shown by the research and other findings.

\section{REFERENCES}

Abere, S.A; Ekeke B.A (2011). "The Nigerian Mangrove and Wildlife Development".

Akinbile, L. A; Salimonu, K.K; Ishola, T. A; (2004). Determinants of production level of commercial snail farmers in Oyo State. Nigeria. African Journal of Livestock Extension, 4 (1), 35-36.

Esio Unanaonwi, O.; Igba Amonum, J. (2014). "Changes in tropical forest vegetation composition: The long term impacts", International Journal of Development and Sustainability, Vol. 3 No. 3, pp. 456-465.

FAO (2007). State of the World's Forests. Food and Agriculture Organisation of the United Nations, Rome, 2007.

Gonzalez, P. (2001). Desertification and a shift of forest species in the West African Sahel. Climate Research 17, 217-228.

IPCC 2007. Climate Change (2007). Impacts, Adaptation and Vulnerability. Contribution of Working Group II to the Fourth Assessment Report of the Intergovernmental Panel on Climate Change, Cambridge University Press.

Nnadi, P.C.; Anyanwu, D.I. (2014). Effects of seed extraction methods, soil media and planting density on the germination and seedling

\begin{abstract}
establishment of chrysophyllum albidium. International journal of Horticulture and Forestry Research 2 (1): 1-8
\end{abstract}

Olajide O. (2016). "Global warming and effects on Nigeria".

Stern, N. (2007). The Economics of Climate Change. Cambridge University Press, 712pp.

Ukoinma, H. N; Abere, S.A; Omokhua, G. E (2014). Andoni marine ecology: Emphasis on the biology and importance of some useful plants. Journal of Environmental and Earth Science. 4(18): 2224-3216.

UNFCCC (1992). United Nations Framework Convention on Climate Change;

Winjim, J. and Schroede, P.E. (1997), "Forest Plantations of the world: their extent, ecological attributes, and carbon storage, Agric. For. Meteorology, Vol. 84, pp. 153167. 